\title{
The forests and elephants of Wayanad: challenges for future conservation
}

\author{
N. R. Anoop ${ }^{1,2, *}$ and T. Ganesh ${ }^{1}$ \\ ${ }^{1}$ Suri Sehgal Centre for Biodiversity and Conservation, Ashoka Trust for Research in Ecology and the Environment, Royal Enclave, \\ Srirampura, Benglauru 560 064, India \\ ${ }^{2}$ Manipal Academy of Higher Education, Manipal 576 504, India
}

\begin{abstract}
The Wayanad district of Kerala, India, is an important conservation and cultural landscape located in the Western Ghats biodiversity hotspot. It is a slightly east-sloping plateau with a unique geographical feature of small rolling hills interspersed with low-lying swamps and meandering streams. Extensive deforestation that occurred in the last century has severely fragmented and degraded the forest of Wayanad, leaving it as a mosaic of forests, wetlands, croplands and towns. The remaining forests in Wayanad are part of the Brahmagiri-Nilgiri-Eastern Ghats Elephant Landscape (NEG), which holds the single largest contiguous population of Asian elephants globally. The NEG is prone to seasonal fluctuation in resource availability, where a large tract of dry forest reduces its carrying capacity for elephants during summer. The Wayanad forests are a critical microhabitat for elephants in the NEG due to availability of fodder and perennial water sources during summer. Despite the importance of this region for elephants, the forest is 'degrading' drastically that will have a far-reaching impact on the long-term conservation of elephants in the NEG. Similarly, human-elephant conflict is on the rise and it is one of the biggest threats to the conservation of elephants and the well-being of rural communities in Wayanad. In this article we identify the current conservation issues and recommend future management of Asian elephants and their habitat in Wayanad.
\end{abstract}

Keywords: Conservation, elephants, habitat management, Wayanad.

THE Wayanad district $\left(110^{\circ} 27^{\prime}-15^{\circ} 58^{\prime} \mathrm{N}, \quad 750^{\circ} 47^{\prime}-\right.$ $700^{\circ} 27^{\prime} \mathrm{E}$ ) in Kerala, India received nation-wide attention owing to its teeming biodiversity, tribal cultures, tourism potential, tropical cash crops, and human-elephant conflict $(\mathrm{HEC})^{1-3}$. It is a slightly east-sloping plateau on the edge of the Western Ghats abutting the dry Deccan plateau to the east. The district is located at a mean elevation of $800-900 \mathrm{~m}$ amsl with a unique geography of small rolling hills interspersed with low-lying swamps ${ }^{4,5}$. Wayanad covers an area of 2130 sq. $\mathrm{km}$, and $40 \%$ of its

\footnotetext{
*For correspondence. (e-mail: anoop.nr@atree.org)
}

area is covered by forest ${ }^{6}$. The district is bounded on the north by Coorg, east by Mysuru and Chamarajanagar districts of Karnataka, on the southeast by Nilgiri district of Tamil Nadu, on the south by Malappuram and on the west by Kozhikode and Kannur districts of Kerala. It has a distinct west-to-east rainfall gradient with less rainfall towards the east due to the orographic effect of the Western Ghats. The western portions of the district receive 2000-5000 $\mathrm{mm}$ annual rainfall, whereas the eastern portions receive $1200-1500 \mathrm{~mm}$ rainfall ${ }^{7}$. The topographic heterogeneity and climatic conditions combine to give rise to a variety of natural ecosystems in Wayanad, harbouring many globally significant species such as the Asian elephant, tiger and wild dog. It is the main watershed for the Kabini river, a major tributary of the Cauvery.

The present-day Wayanad district was a Taluka (an administrative unit) of Malabar district, which was under the reign of Madras Province. The Gudalur region of Tamil Nadu was also part of the Wayanad Taluka, but it was added to the Nilgiri district in 1877 for administrative purposes ${ }^{8}$. Prior to the advent of the British, Wayanad was under the rule of several realms. According to Nair ${ }^{8}$, Wayanad was ruled by Vedar (Mullu Kurumar) kings during the 14th and 15th centuries. The Kottayam and Kurumbranad kingdoms of northern Kerala defeated the Vedar kings and ruled the area for a long span of time. Wayanad was also a territory of Hyder Ali and his son Tippu Sultan who ruled the adjacent Mysore kingdom. After the death of Tippu Sultan in the Seringapatam war in 1799, Wayanad became part of the British Empire and the region was integrated with the Madras Presidency for administrative proposes, despite some resistance from Kerala Varma Raja of Kottayam who fought against the British and was killed in 1805.

Prior to the arrival of the British, the population in Wayanad was small and scattered; the people practised small-scale cultivation and this had insignificant impact on the environment ${ }^{1,8}$. Currently, Wayanad is the least populated district in Kerala with a population of 817,420 and population density of 384 persons per sq. $\mathrm{km}$. It is a tribal district with 11 different tribal communities constituting $18.5 \%$ of its total population ${ }^{6,9}$. They have distinct cultural identities and a large proportion of the population 
depends directly on the forest for subsistence ${ }^{2}$. The major crops grown here are coffee, pepper, tea and paddy ${ }^{6}$.

The British administration greatly influenced in shaping the economic, ecological and social system in Wayanad. With their arrival, Wayanad was exposed to largescale land-cover transformation. The colonial government maximized revenue chiefly through the production systems such as plantation economy and extraction of timber $^{8,10}$. Since the landscape was unruly for the British due to its extreme climate, geography and disease prevalence, they captured and trained several free-ranging elephants with the help of the tribals and the skills of both of these were utilized to exploit the natural resources to increase the revenue of the government ${ }^{8,11}$. Similarly, they used fire as a tool to open up the forest to eliminate malaria which was prevalent in Wayanad and adjacent areas. Subsequently, plantations of coffee, cinchona, tea and hardwood trees were established while timber was cut from the forests, and road networks to facilitate the transport of natural resources were formed. Further, hundreds of workers were brought to Wayanad from neighbouring areas to work in the estates, which further added pressure on the forests of Wayanad ${ }^{8}$. In spite of such changes in the land use during the colonial rule, most of Wayanad was still forested ${ }^{12}$. It was the post-colonial era which witnessed extensive and widespread land-use and landcover change that had a significant impact on the forests and biodiversity in the region.

Wayanad witnessed large-scale inward migration of people from the former princely state of Travancore from 1920s. The migration continued till 1970 and was at its peak between 1955 and 1965 (refs 1, 12 and 13). This migration was attributed to famine and population growth in Travancore ${ }^{13}$. The Government encouraged people to establish farmlands in private forests to lessen the impacts of famine and accommodate an increasing population $^{1,12}$. The migrants extended the agrarian frontiers deep into the forests of Wayanad and in the process severely fragmented and reduced the forests into two narrow tracts along the western and eastern borders of the district. The rugged and narrow forest belt along the western boundary harbouring a few peaks greater than $2000 \mathrm{~m}$ amsl is mostly evergreen with high biological diversity, but is also highly fragmented. The deciduous forest along the eastern boundary is, however, more contiguous with the protected areas of Tamil Nadu and Karnataka.

In this article, we discuss the conservation issues of the deciduous forest belt in Wayanad (Wayanad plateau hereafter). This tract includes Wayanad Wildlife Sanctuary (WWS; 344.44 sq. km), Chedalayam (86 sq. km) and Begur (89.5 sq. km) forest ranges.

The Tholpetty Range of WWS and Begur Range North Wayanad Forest Division of the plateau are located in the north bank of the Kabini and the remaining three ranges of WWS and Chethalayam Range of South Wayanad Forest Division are located in the south bank of the
Kabini. The Tholpetty and Begur Ranges connect to a large area of wet evergreen-grassland complex (Brahmagiris) to the west through the narrow 'Thirunelli-Kudrekote elephant corridor' and contiguous with Nagarahole National Park of Karnataka to the east ${ }^{14}$. The Southern ranges are well connected to the protected areas of Tamil Nadu and Karnataka to the east. However, connectivity to the forests along the main Western Ghats ridge is lost due to encroachment in Wayanad and Gudalur areas in the recent past. The Chethalayam Range is an isolated and irregularly shaped forest patch skirting along the western boundary of Pulpally area. The connectivity of the Wayanad plateau is completely disrupted within the district by the Pulpally settlements on the right bank of the Kabini ${ }^{5}$. The connectivity of this range to the forests in the north is disrupted by the encroachments from Palvelicham till Bavali along the north bank of the Kabini in Kerala and from Bavali to DB Kuppe in Karnataka and towards south by the encroachment in the Mariyanad-Irulam areas south of Pulpally (Figure 1). The chief vegetation types in the plateau are moist deciduous and dry deciduous forests interspersed with plantations of teak and eucalyptus.

\section{Wayanad plateau and its importance for elephants}

The Brahmagiri-Nilgiri Eastern Ghats Elephant Landscape (NEG) of southern India holds the single largest breeding population of Asian elephants globally and is considered as one the key landscapes for the long-term survival of this mega-herbivore ${ }^{15,16}$. This landscape extends from the Brahmagiri hills through the Wayanad plateau into the forests in the northern Nilgiri hill slopes which link up to the Eastern Ghats ${ }^{15}$. Due to the gradient of vegetation and asynchrony in rainfall pattern, the NEG experiences spatio-temporal variation in resource availability ${ }^{17,18}$. Most parts of the NEG in the drier Sigur and Mysore plateaus experience decline in quantity and quality of resources for elephants during the long summer months ${ }^{18}$. The grass becomes fibrous and less nutritious, and most of the stream channels become dry ${ }^{17,18}$.

The Wayanad district and the adjacent Coorg and Gudalur areas which extend northwest of the Nilgiri plateau were the key moist forest reaches within the extensive NEG. Due to heavy deforestation and modern forestry practices during the last century, this tract has been converted into an agriculture landscape. Currently, the Wayanad plateau is the only remaining forest in this tract which is accessible to elephants in the NEG. Studies have reported a large concentration of elephants and other large herbivores in the WWS during summer months ${ }^{19,20}$. The plateau is also an important habitat for large carnivores with 75 tigers and 31 leopards recorded from the $\mathrm{WWS}^{21}$. Despite the importance of Wayanad plateau 


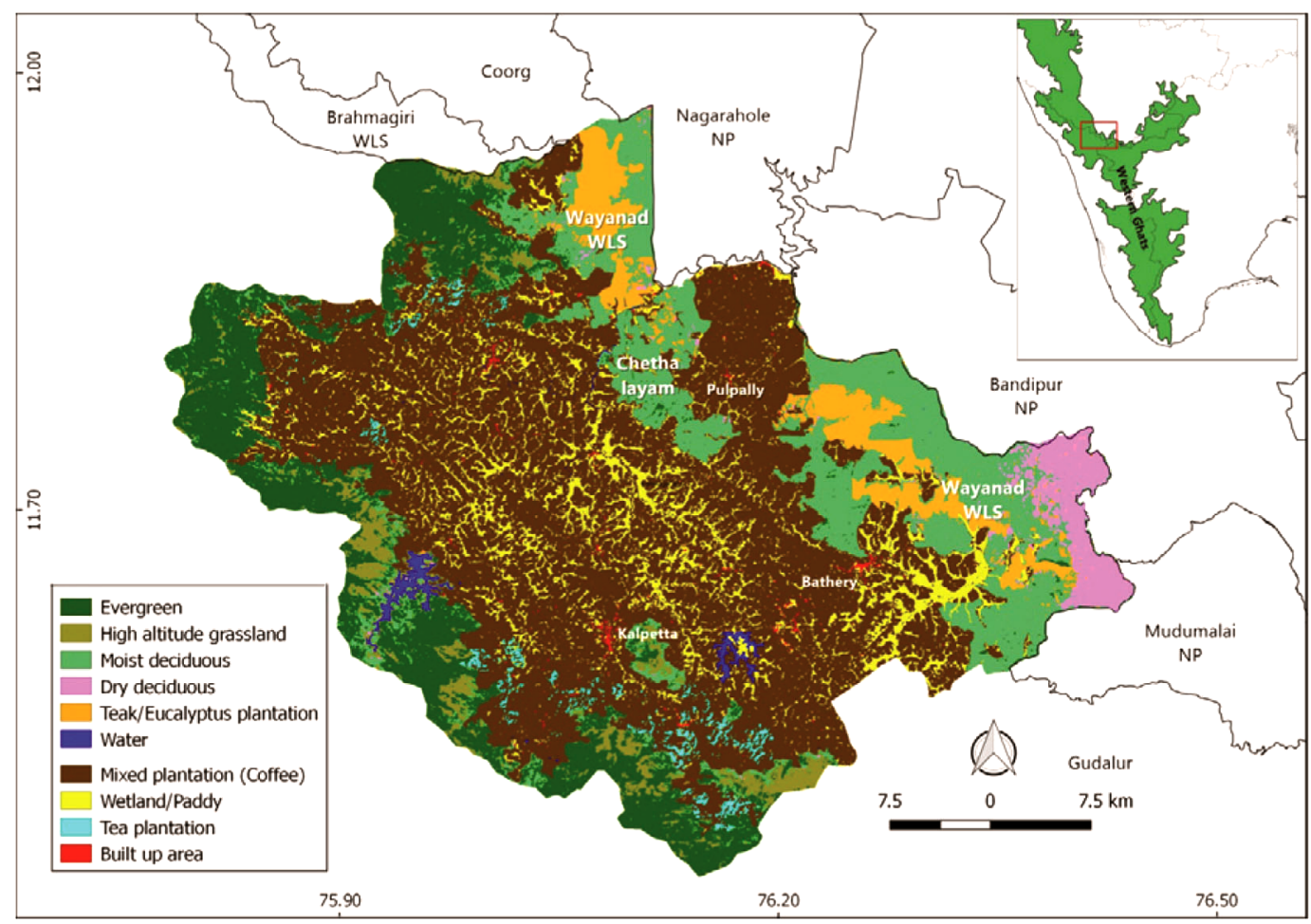

Figure 1. Land-cover map of Wayanad district, Kerala, India.

for elephants in the NEG, little research has been carried out on elephants here and the forest is degrading drastically due to various anthropogenic pressures such as habitat degradation, increasing human-wildlife conflict, spread and establishment of invasive species, and manmade forest fire.

\section{Invasive plants making Wayanad a green desert}

Historical forest modifications such as commercial forestry operations and forest fire have degraded the forests and severely altered the floristic composition and structure in Wayanad plateau. Currently, the vegetation in the plateau is in different stages of its secondary succession ${ }^{5}$. This provided an opportunity for the extensive spread and establishment of various invasive plants. Lantana camara is the dominant undergrowth in the WWS and exotic tree Senna spectabilis is spreading extensively. Presently, about $25 \%$ area of the WWS is invaded by $S$. spectabilis (Anoop and Ganesh, unpublished). Other invasive species such as Chromoleana odorata, and Parthenium hysterophorus are also established in the plateau. The invasive plants negatively influence the composition and structure of native vegetation and regeneration of native plant species $^{22-24}$. Also, the thick shield of L. camara prevents herbivores to access the forage $\mathrm{e}^{22}$. In addition, the invasive species are non-palatable for herbivores which can reduce the carrying capacity of the habitat especially for megaherbivores like elephants which need a large quantity of forage for survival. The extensive spreading of invasive plants can also influence the behaviour of elephants and leads to $\mathrm{HEC}^{23,25}$. However, little information is available on the spread and habitat degradation caused by invasive plants on the native biodiversity in Wayanad.

\section{Man-made fire is a major conservation issue in Wayanad}

Fire makes forest ecosystems susceptible to invasion, alters soil chemistry and kills microfauna and flora, reduces water percolation and infiltration, triggers soil erosion and alters vegetation composition and structure ${ }^{26-28}$. Fire is a common disturbance factor and one of the major drivers of habitat degradation and loss of biodiversity in Wayanad. Fire occurs almost during all dry seasons with varied intensity and severity. For instance, between 2001 and 2011, an area of 4751 ha of forest was burnt in 316 fire incidents in the WWS alone ${ }^{20}$. There is a low probability of fire due to non-human sources in Wayanad; it is largely manmade. At times, forest fire is a protest strategy against the Forest Department.

Bamboo (Bamboosa spp.) is common in the Wayanad forests and is an important food source for elephants ${ }^{19}$. Gregarious flowering of bamboo happens every 40-50 years and the plant dies after producing seeds. Fire during the flowering and fruiting season can destroy the seed bank and the entire population of bamboo. For example, high-intensity fires followed by bamboo flowering in 


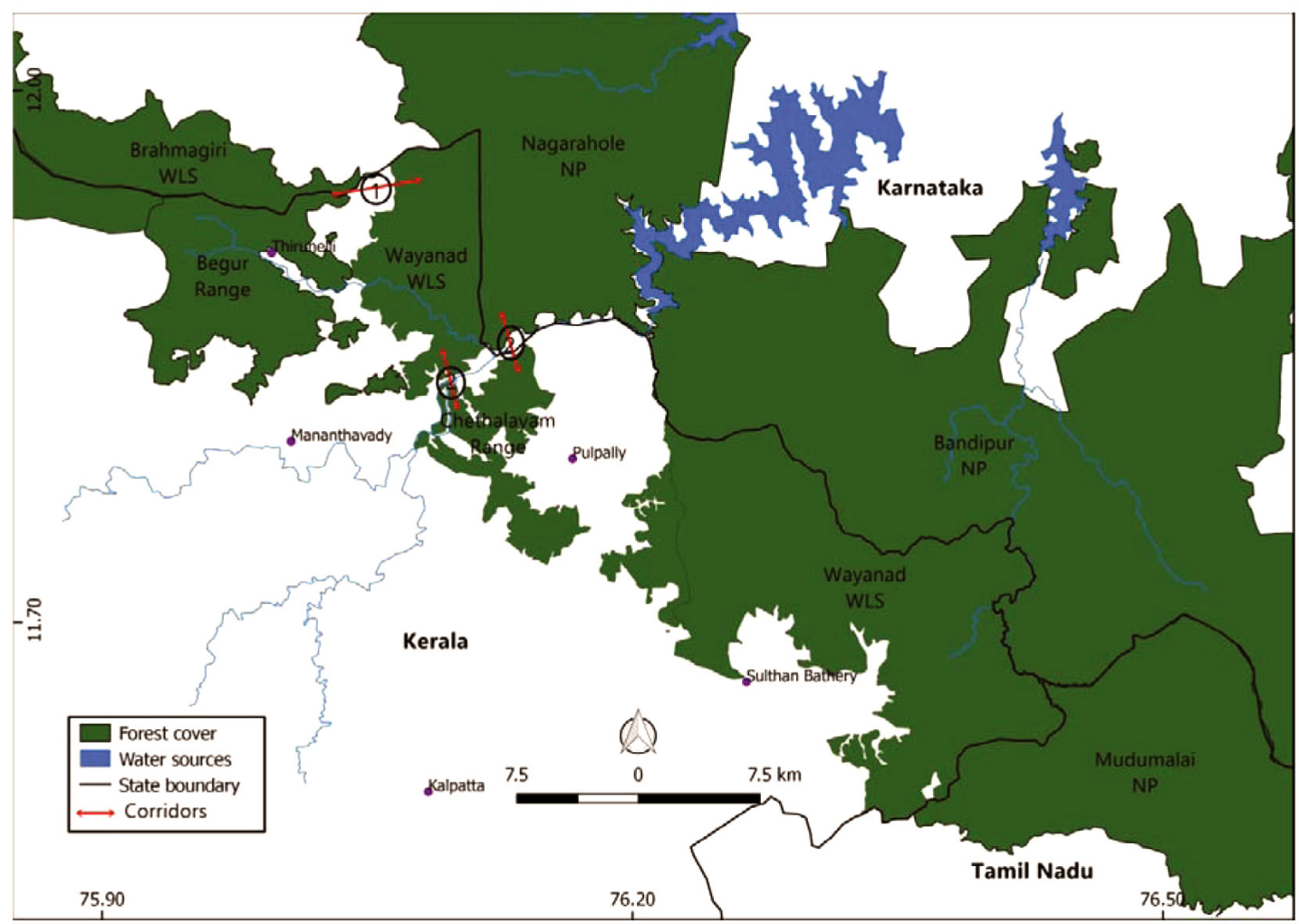

Figure 2. Map showing the functional corridors of elephants through the non-forest land-use class in the Wayanad plateau (1. Tholpetty-Brahmagiri and 2. Nagarahole-Chedalayam).

Thirunelli-Kudrekote elephant corridor in 2008-10 led to poor regeneration of the species in the area.

\section{Human-elephant conflict and its mitigation}

The Wayanad plateau is a hotspot of HEC and it is a major challenge for biodiversity conservation and wellbeing of rural communities. In the last ten years, 32 people lost their lives in Wayanad district due to HEC situations and a huge amount of money was paid as compensation for crop loss ${ }^{20}$. Also, the conflict situation leads to the death of several elephants, especially from illegal high-voltage electric fences and poisoning ${ }^{29-32}$. However, few quantitative data are available on the pattern and drivers of conflict and its indirect impact on biodiversity, including habitat degradation. A considerable number of elephants reside in the isolated Chethalayam Range and they are in severe conflict with the local people. Interviews with local residents and Forest Department officials revealed that the population of elephants in this Range has increased considerably over the last 15 years. However, baseline information on elephants is lacking from this Range, including their number, dispersal from adjacent forests, mortality and habitat utilization. This information needs to be gathered urgently to develop a site-specific management plan. For instance, elephants from Chethalayam are increasingly venturing farther away from the forests exposing themselves to very high risk, but we have a poor understanding of such behaviour and its drivers.

\section{Protection of swamps (vayals)}

The presence of slushy swamps is a unique geographical feature of the Wayanad plateau. The swamps have deep black clay soil that gets waterlogged during the rainy season. The surface run-off of these marshes is poor, which allows for maximum water percolation and hence maintenance of a high water table in the region ${ }^{7}$. These swamps are important micro-habitats for elephants in the NEG, which ensure forage and water for them and other large mammals during summer ${ }^{19}$. These swamps are now facing various threats, including the spread of invasive species, degradation of catchment areas, creation of ponds and check dams. Fire in the catchment area is a major threat to these swamps by reducing water percolation ability of the soil through the removal of leaf litter, humus and vegetation cover. Most of the swamps in Wayanad district which were used by elephants in the past are used for paddy cultivation at rest, and what is left is only inside the $\mathrm{WWS}^{20}$. Hence special attention needs to be given to the management of these swamps in Wayanad, and their utilization by elephants needs to be studied in detail. 


\section{Conclusion and recommendations}

The forests in Wayanad are facing several threats as highlighted above, which can worsen the situation not only for wildlife but also affect the livelihood of people, especially in the context of the current global climate change scenario. We need to take proactive measures to address these issues that would involve multiple stakeholders across multiple scales. We highlight some of the urgent measures that need to be addressed.

We recommend developing a detailed eco-restoration plan for Wayanad forests. The restoration process must make sure to involve the local community and selection of species must be based on the resource necessity for wildlife and community requirement. Currently, the 'unsustainable' commercial harvest of non-timber forest products (NTFP) is leading to the decline of forest produce in Wayanad. For example, our discussion with NTFP gatherers revealed that Solanum torvum and Sida cordifolia have reduced drastically in the area during the last 10 years. Eco-restoration will also help reduce the HEC through enhancing food and water availability inside the forest. Along with restoration, forest fire and livestock grazing need to be controlled. Spreading and establishment of invasive species is of considerable concern for maintaining ecosystem functioning as well as biodiversity. Hence, we also recommend conducting urgent research on the ecological impact of invasive plants and their management in Wayanad.

Identifying functional corridors and their management is important for the conservation of elephants in fragmented landscape like Wayanad. The Tirunelli-Kudrakote corridor in the Wayanad plateau is considered to be one of the high priority corridors in the country. It connects the Brahmagiri hills to the west and NBR to the east through Begur and Tholpetty Ranges ${ }^{14}$. The elephant corridors in the district have been identified based on structural connectivity, but not necessarily based on functionality ${ }^{14}$. Hence identifying all functional corridors of elephants inside and outside forest areas will greatly contribute to their management and in reducing HEC. For example, we have identified two functional corridors through agriculture land-use class which is frequently used by the elephants, viz. Nagarahole-Chedalayam and Tholpetty-Brahmagiri (Figure 2). The first corridor is located between Nagarahole National Park and Tholpetty Range of the WWS in the left bank of the Kabini and Chethalayam Range in the right bank of the Kabini. The second corridor is located between the northwestern corner of the Tholpetty Range and the eastern slope of the Brahmagiri hills along the state boundary. There might be several other functional corridors going through nonforest areas. Identifying and acquiring these corridors will greatly enhance the movement of elephants in this fragmented landscape.
There are four major roads passing through the WWS. Three National Highways which connect BatheryGundalpet (NH 766) through the Muthanga Range, Mananthavady-Mysore (NH 67), and Kartikulam-Coorg through the Tholpetty Range, in addition to the BatheryPulpally road passing through the Kurichyat Range of the WWS. NH 766 is along the Nugu River from Muthanga check-post till the state border. Since 2009 traffic between 9 pm and 6 am was banned in both NH 766 and NH 67. This helped in reducing road kills along these highways $^{29}$. But now the Kartikulam-Coorg road is being used as the alternate route during the night, which poses severe pressure on wildlife in the Tholpetty Range. Vehicle-induced mortality is now common along this road. We suggest deploying speed breakers along roads to control the speed of the vehicles, and recommend shifting the check posts and eateries along NH 766 to outside forests and impose strict measures on waste dumping inside forest areas. Reducing vehicular pressure along the Tholpetty Range during night hours is essential for the easy movement of elephants and other animals. The tourism activities in the area need to be controlled, especially the night safari along the Thirunelli-Kudrekote elephant corridor and Tholpetty Range.

Wayanad plateau is highly fragmented and irregular in shape with several enclosures within and in the periphery of the forests. Here the social-ecological milieu surrounding forest areas is changing quickly and human population is showing an increasing trend. Hence, HEC mitigation needs high priority since it can seriously affect conservation activities in the region. Prevalence of zoonotic diseases such as $M$. tuberculosis and herpes virus are reported in free-ranging elephants of Wayanad ${ }^{30,31}$. Therefore, veterinary intervention in the landscape is essential to control the spread of epidemic diseases to wildlife from livestock and human. Finally, we recommend initiating long-term research on elephants in Wayanad, which is essential for scientifically sound management of elephants and their habitat.

1. George, J. and Krishnaprasad, P., Agrarian distress and farmers' suicides in the tribal district of Wayanad. Soc. Sci., 2006, 34, 7085 .

2. Münster, U. and Vishnudas, S., In the jungle of law: adivasi rights and implementation of Forest Rights Act in Kerala. Econ. Polit. Wkly., 2012, 47, 38-45.

3. Münster, D. and Münster, U., Consuming the forest in an environment of crisis: nature tourism, forest conservation and neoliberal agriculture in South India. Dev. Change, 2012, 43, 205-227.

4. Nair, S. C., The Southern Western Ghats; A Biodiversity Conservation Plan. Studies in Ecology and Sustainable Development, vol. 4, Indian National Trust for Art and Cultural Heritage INTACH, New Delhi, 1991.

5. Nair, S. C., Nair, P. V., Sharatchandra, H. C. and Gadgil, M., An ecological reconnaissance of the proposed Jawahar National Park. J. Bombay Nat. Hist. Soc., 1977, 74, 401-435.

6. Census of India, District Sensus Handbook, Wayanad, Directorate of Census Operations, Thiruvananthapuram, 2011, p. 153. 
REVIEW ARTICLE

7. Nair, S. C., Long-term conservation potential of natural forest in the southern western Ghats of Kerala, Department of Environment, Government of India, 1998

8. Nair, C. G., Wynad: Its People and Traditions, 1911, Higginbotham and Company, p. 160.

9. Varghese, S. P., Pradeep, C. K. and Vrinda, K. B., Mushrooms of tribal importance in Wayanad area of Kerala. J. Mycopathol. Res., 2010, 48, 311-320

10. Mathew, J., Plantation economy in colonial Malabar - with special reference to Wayanad. Proc. Indian Hist. Congress, 2006-07, pp. 730-737.

11. Münster, U., Invisible labor: Adivasi workers in the history of South Indian forest conservation. In Asian Environments: Connections across Borders, Landscapes, and Times (eds Münster, U., Satsuka, S. and Cederlöf, G.), RCC Perspectives, 2014, no. 3, pp. 53-58.

12. Easa, P. S. and Sankar, S., Study on man-wildlife interaction in Wayanad Wildlife Sanctuary, Kerala, Kerala Forest Research Institute, Peechi, 2001, p. 82.

13. Joseph, J., Peasant migration to Malabar with a special reference to Peravoor settlement (1925-1970). Proc. Indian Hist. Congress, 2008, 69, 1178-1187.

14. Menon, V., Tiwari, S. K., Easa, P. S. and Sukumar, R., Right of Passage: Elephant Corridors of India, Wildlife Trust of India. New Delhi, 2005.

15. Rangarajan, M. et al., Securing the future for elephants. The report of the Elephant Task Force, Ministry of Environment and Forests, Government of India, 2010, p. 187.

16. Baskaran, N., An overview of Asian elephants in the Western Ghats, southern India: implications for the conservation of Western Ghats ecology. J. Threat. Taxa, 2013, 5, 4854-4870; http://dx.doi.org/10.11609/JoTT.o3634.4854-70

17. Sukumar, R., Ecology of the Asian elephant in southern India. I .Movement and habitat utilization patterns. J. Trop. Ecol., 1989, 5, $1-18$.

18. Sivaganesan, N., The ecology of the Asian elephant in Mudumalai Wildlife Sanctuary with special reference to habitat utilization. $\mathrm{Ph}$ D thesis, Bharathidasan University, Tiruchirapalli, 1991.

19. Easa, P. S., Status, habitat utilization and movement pattern of larger mammals in Wayanad Wildlife Sanctuary, Research Report No. 134, Kerala Forest Research Institute, Peechi, 1999, p. 166.

20. Kumar, K. K. S., Wayanad Wildlife Sanctuary-Management plan, 2012-2022. Forests and Wildlife Department, Government of Kerala, 2012, p. 230.

21. Narasimen, R. K., Kumar, A. M., Jayam, P. P. C., Chinnaiyan, S., Nagarathinam, M. and Desai, A. A., Status of tigers, co-predators and prey in the Wayanad Wildlife Sanctuary, Kerala, WWF-India, Delhi, 2013.

22. Prasad, A. E., Effects of an exotic plant invasion on native understory plants in a tropical dry forest. Conserv. Biol., 2010, 24, 747757.

23. Prasad, S., Witt, A., Williams, A. C. and Sitompul, A., Invasive plant species in Asian elephant habitats. Aliens: Invas. Species Bull., 2011, 31, 30-35.

24. Sundaram, B. and Hiremath, A. J., Lantana camara invasion in a heterogeneous landscape: patterns of spread and correlation with changes in native vegetation. Biol. Invasions. 2012, 14, 11271141.

25. Wilson, G., Desai, A. A., Sim, D. A. and Linklater, W. L., The influence of the invasive weed Lantana camara on elephant habitat use in Mudumalai Tiger Reserve, southern India. J. Trop. Ecol., 2013, 29, 199-207.

26. Hiremath, A. J. and Sundaram, B., The fire-lantana cycle hypothesis in Indian forests. Conserv. Soc., 2005, 3, 26-42.

27. Cochrane, M. A., Fire science for rainforests. Nature, 2003, 421, 913-919.

28. Verma, S. and Jayakumar, S., Impact of forest fire on physical, chemical and biological properties of soil: a review. Proc. Int. Acad. Ecol. Environ. Sci., 2012, 2, 168-176.

29. The Hindu, With ban on night traffic, Bandipur road kills down, 5 July 2018.

30. Zachariah, A., Zong, J. C., Long, S. Y., Latimer, E. M., Heaggans, S. Y., Richman, L. K. and Hayward, G. S., Fatal herpesvirus hemorrhagic disease in wild and orphan Asian elephants in southern India. J. Wildl. Dis., 2013, 49, 381-393.

31. Zachariah, A., Pandiyan, J., Madhavilatha, G. K., Mundayoor, S., Chandramohan, B., Sajesh, P. K. and Mikota, S. K., Mycobacterium tuberculosis in wild Asian elephants, southern India. Emerg. Infect. Dis., 2017, 23, 504.

32. Rajeev, K. R., Illegal electric fences turn jumbo killers in Kerala, Times of India, 21 June 2019.

ACKNOWLEDGEMENTS. We thank the Kerala Forests and Wildlife Department, Thiruvananthapuram for granting permission and facilitating the fieldwork. This project is funded by ATREE academy and the Rufford Foundation for Nature Conservation, UK. We thank Ferns Nature Conservation Society, especially P. A. Vinayan for discussions and support during the field work.

Received 11 November 2019; accepted 31 December 2019

doi: $10.18520 / \mathrm{cs} / \mathrm{v} 118 / \mathrm{i} 3 / 362-367$ 